Forthcoming in Arrogance and Polarization. Eds. A. Tanesini and M. Lynch. Routledge.

\title{
Intellectual Humility and the Curse of Knowledge
}

\author{
Michael Hannon \\ University of Nottingham
}

\begin{abstract}
This chapter explores an unappreciated psychological dimension of intellectual humility. In particular, I argue there is a plausible connection between intellectual humility and epistemic egocentrism. Epistemic egocentrism is a well-known cognitive bias - often called 'the curse of knowledge' - whereby an agent attributes his or her own mental states to other people. I hypothesize that an individual who exhibits this bias is more likely to possess a variety of traits that are characteristic of intellectual humility. This is surprising because intellectual humility is often regarded as an antidote to cognitive biases, whereas I claim that a particular cognitive bias (namely, the curse of knowledge) may help foster an intellectual virtue.
\end{abstract}

\section{Introduction}

Intellectual humility is widely considered a virtue. ${ }^{1}$ Although there is no consensus within philosophy or psychology on a precise definition of intellectual humility, it has been linked to an assortment of desirable traits. For example, intellectual humble people have been said to: not think too highly of themselves; not ascribe to themselves greater excellence than they possesses; show low concern for how special their talents are; take complaints and criticism seriously; generously acknowledge the contributions of others; and not demand special treatment, even

\footnotetext{
${ }^{1}$ For example, see Church and Barrett (2016), Hazlett (2012), Roberts and Wood (2003), Samuelson et al. (2015), Tanesini (2018), and Whitcomb et al. (2017).
} 
when deserving. This virtue has been studied by philosophers, psychologists, and theologians, and it seems to involve a mix of cognitive, emotional, behavioural, and motivational components.

This chapter will explore a surprising and unappreciated psychological underpinning of intellectual humility. In particular, I will argue there is a plausible connection between intellectual humility and epistemic egocentrism.

Epistemic egocentrism is a well-known cognitive bias whereby an agent attributes his or her own mental states to other people. ${ }^{2}$ For example, a brilliant professor who no longer remembers the difficulties that a young student encounters when learning a new subject, and who therefore mistakenly assumes that students will find difficult material easy to grasp, is being epistemically egocentric. Epistemic egocentrism is often called 'the curse of knowledge' because it can lead to suboptimal results in a variety of domains; for instance, imputing one's knowledge to other people can make it difficult to teach novices and harder to communicate. Nevertheless, I want to consider the role that the imputation of one's own knowledge to others might play in the possession of intellectual humility. The central question of this chapter is: are the epistemically egocentric more likely to be intellectually humble? I believe we have some reason to think so.

\section{Epistemic Egocentrism}

Let me first say a bit more about epistemic egocentrism. As mentioned above, it is a cognitive bias whereby we attribute our own mental states to other people, as well as our own past selves. Consider the fact that second-time readers of a good suspense novel will often overestimate the predictability of certain plot twists and character developments. This is because our privileged knowledge affects how we reimagine or re-experience various details of story. Once we know

\footnotetext{
${ }^{2}$ Epistemic egocentrism may also be linked to other biases, such as the hindsight bias (where an event seems predictable after it has occurred) and the false consensus effect (where we tend to overestimate the commonness of our own beliefs and choices). See Nickerson (1999) for a review.
} 
something, we find it difficult to set aside our 'privileged information', which is information that we possess but others lack. ${ }^{3}$ Epistemic egocentrism is therefore a form a perspective-taking failure.

In 1990, a Stanford graduate student in psychology named Elizabeth Newton illustrated this phenomenon with a simple game in which participants were assigned one of two roles: "tapper" or "listener". Each tapper was asked to pick a well-known song, such as "Happy Birthday," and tap out the rhythm on a table. The listener's job was to guess the song. Tappers were also asked to predict how often the listener would guess correctly: they predicted $50 \%$. But, in fact, the listeners were only able to guess three of the 120 songs - a success ratio of $2.5 \% .{ }^{4}$ What explains this?

Once you know something, it is very difficult to remember what it was like not to know it-to put yourself in the shoes of someone who lacks your knowledge. As a result, we become overly confident in other people's cognitive abilities. To use a bit of philosophical jargon, we tend to assume that other people are in a stronger epistemic position than they really are. In the example of tappers and listeners, the tapper will hear the song in their head as they tap, but they will also forget what it was like to not have this privileged knowledge. As a result, they mistakenly assume that others will find the task easier than it is.

The tendency to see the world from an epistemically egocentric perspective is a general feature of human cognition (see Nickerson 1999; Royzman et al. 2003). This explains why company employees will use acronyms that newcomers do not understand, why doctors use complex medical terms in discussion with patients, and why my girlfriend finds it so frustrating to play charades with me.

\footnotetext{
${ }^{3}$ Privileged information could be about some publicly accessible fact to which others lack physical access (e.g. the location of a physical object), or it could be a fact of one's private consciousness (e.g., an undisclosed thought). Privileged information may also be highly concrete or abstract.

${ }^{4}$ Reported in Heath and Heath (2006).
} 
Epistemic egocentrism becomes 'the curse of knowledge' when it leads to suboptimal results. For example, it can interfere with our ability to communicate and explain, make it more difficult for others to learn from us, lead patients to misunderstand their doctors, and ruin family game night. To overcome our epistemically egocentric tendencies, we must somehow eschew our privileged knowledge. This calls for a two-step process: first, we must distinguish information that is to be retained (i.e. shared knowledge) from information that is to be disregarded (i.e. privileged information); second, we must inhibit the information that is to be disregarded. ${ }^{5}$ According to Johnson's (1998) review of the literature, people have difficulty with both tasks. Furthermore, insufficient separation (the first step) and poor inhibition (the second step) are individually sufficient to yield an epistemically egocentric result.

Epistemic egocentrism is often regarded as a curse, but the tendency to skew towards our own privileged viewpoint may not be entirely bad. As I advertised at the start of this chapter, I believe that epistemic egocentrism may help foster intellectual humility. To explain why, I must first review some key findings from the literature on intellectual humility.

\section{Intellectual Humility}

Although the study of intellectual humility is fairly new, philosophers and psychologists have already offered a variety of accounts of this virtue. Unfortunately, there is little agreement on how to define intellectual humility. ${ }^{6}$ Instead of providing a definition, I will briefly survey the literature and draw out a list of qualities commonly associated with intellectual humility.

\footnotetext{
${ }^{5}$ See Johnson (1998) for a more detailed discussion.

${ }^{6}$ In his overview of the literature, Ballantyne (MS) writes: "researchers don't concur on how to define intellectual humility precisely". Likewise, Alfano et al. (2017) say: "no consensus emerges within philosophy or psychology on a precise definition of intellectual humility". Nadelhoffer et al. (2017) make a similar observation.
} 
Let's start with a traditional view of humility. ${ }^{7}$ According to this view, humility involves a low view of one's accomplishments or self-worth. St. Thomas Aquinas, for example, says that being humble involves "self-abasement to the lowest place" ([1485] 1972). Likewise, Sidgwick says, "humility prescribes a low opinion of our merits" (1907/1962: 334) and the Oxford English Dictionary defines humility as "having a lowly opinion of oneself" (McAuthur 1998). Let's call this the "low self-estimate view".

A low estimate of oneself may be accurate or not. Thus, the low self-estimate view actually bifurcates into two views. On the one hand, intellectual humility may require us to take a properly low view of ourselves. I will call this the "accurate low self-estimate view". Consider, for instance, the following remark by Aquinas: "it is possible, without falsehood, to deem and avow oneself the most despicable of men ... [and] without falsehood one may avow and believe oneself in all ways unprofitable and useless in respect of one's own capability" (st ii-ii Q. 161 Art. 6 ad.1). ${ }^{8}$ On the other hand, intellectual humility may require us to underestimate our intellectual strengths and self-worth. As Julia Driver maintains, the humble person "is disposed to underestimate self-worth to some limited extent, in spite of the available evidence" (2001: 21). ${ }^{9}$ Let's call this the "underestimation view". This view requires an inaccurate assessment of one's accomplishments and abilities. ${ }^{10}$

\footnotetext{
${ }^{7}$ I am here following many others (e.g. Roberts and Wood 2003) in assuming that intellectual humility is a sub-species of humility.

8 In The Cloud of Unknowing, an anonymous work of Christian mysticism written in the 14th century, the author declares that humility is "nothing else but a true knowledge and experience of yourself as you are, a wretch, filth, far worse than nothing." Similarly, Gabrielle Taylor (1985: 17) says, "the man who accepts his lowly position as what is due him is the man who has humility, or the humble man".

${ }^{9}$ Driver is actually writing about modesty, not humility, but these two concepts are closely related. Indeed, some explicitly treat "modesty" and "humility" as interchangeable (Hare 1996, Garcia 2006, and Sinha 2011). An empirical study has also shown that modesty is one of the core dimensions of humility (Alfano et al. 2017). See Allhoff (2009) for an attempt to distinguish humility from modesty.

${ }^{10}$ Underestimation does not actually require a low self-estimation because a humble person could still have "a rather high opinion of herself, just not as high as she is entitled to have" (Driver 2001: 19). It is therefore somewhat misleading to characterize the underestimation view as a low self-estimate view. Still, underestimation involves a relatively low self-estimate because it is low compared to what one is entitled.
} 
The accurate low self-estimate view is often tied to a specifically religious conception of humility. This view makes sense in a religious context because it is easy to acknowledge our lowliness and insignificance in relation to God's greatness (and presupposing original sin). For those who do not share certain religious beliefs, however, the claim that we are worthless, despicable, and corrupt will seem inaccurate. Indeed, this view of humility led Spinoza, Hume, Nietzsche, and Sidgwick to criticize humility and claim it is not a virtue. ${ }^{11}$ I will therefore set this view aside and focus on contemporary secular accounts of humility.

The underestimation view gets something right about humility: it provides an antidote to pride and hubris. By all accounts, the intellectually humble lack the characteristic dispositions involved in excessive intellectual self-regard, such as pride, intellectual arrogance, and so on. But many philosophers think humility does not require us to undervalue ourselves and our capabilities. ${ }^{12}$ This is because a person might recognize his or her accomplishments, skills, talents, etc. and yet still be humble about them, taking little pride in them. As Jorge Garcia (2006: 422) puts it, the issue seems to be about our "affective and volitional response" to our self-ascribed good features, not our "beliefs about them". Thus, being humble does not seem to require mistaken beliefs or thinking poorly of oneself.

Many scholars therefore prefer a conception of humility whereby the intellectually humble can recognize their own value and abilities, although they will not give these much thought or grant them much importance. As C.S. Lewis (2012) wrote, "Humility is not thinking less of yourself but thinking of yourself less". Likewise, Roberts and Wood (2003: 271) characterize intellectual humility as

an unusually low dispositional concern for the kind of status that accrues to persons who are viewed by their intellectual communities as intellectually talented, accomplished, and

\footnotetext{
${ }^{11}$ See Nadelhoffer et al. (2017) for a fascinating overview of the tangled history of humility in theology and philosophy.

${ }^{12}$ See Garcia (2006) and Nadelhoffer et al. (2017), for example.
} 
skilled, especially where such concern is muted or sidelined by intrinsic intellectual

concerns.

This definition has drawn considerable philosophical interest. According to this perspective, intellectual humility can be thought of as a low concern for status or self-importance, perhaps in addition to a high concern for knowledge and its various attributes (truth, justification, etc.). Let's call this the "low self-concern view". ${ }^{13}$

A related view of humility is the "non-overestimation view", where one is required to not overestimate one's worth and accomplishments. Flanagan, for example, says the humble person "may have a perfectly accurate sense of her accomplishments and worth but she does not overestimate them" (1996: 176). Likewise, Richards says "being humble is not a matter of thinking that one's accomplishments and virtues come literally to naught, but just of esteeming them no more highly than they deserve" (1992: xii). ${ }^{14}$ This conception of humility, unlike the underestimation view, does not require the humble person to be ignorant of (or inaccurate about) her worth and accomplishments. Rather, one must not distort or otherwise self-enhance to make oneself look and feel better.

The inadequacy of the low self-estimation view, coupled with the plausibility of the low selfconcern view, might lead one to prefer Tangney's $(2000,2009)$ account of humility. She says humility involves a moderate or accurate assessment of the self (i.e. not a low estimation and not an overestimation) as well as a low self-focus (i.e. a relative lack of preoccupation with one's

\footnotetext{
${ }^{13}$ We must be careful not to confuse low self-concern with a low estimation of oneself. An individual might have a high concern for status or self-importance and yet also have a very low estimation of their own status or importance. Thus, low self-concern and low self-estimation are not the same thing. It is also worth noting that the low self-concern view may be distinguished from the view that humility requires us to be unconcerned with the opinions of others (see Schueler 1997: 283; Roberts and Wood 2003: 261). It is plausible that the humble person generally does not care too much about whether others are impressed by her accomplishments or skills. But this is not a sufficient condition for humility, as illustrated by the Nietzschean overman's disdain for others' slights, praise, or fawning (see Garcia 2006: 423).

${ }^{14}$ Not overestimating one's accomplishments and worth is not sufficient for humility. That would leave no middle ground for individuals who are neither arrogant nor humble. We need to make room for people who do not overestimate their own accomplishments and virtues and yet still are not humble.
} 
accomplishments or worth). This seems to combine the low self-concern view with a secular version of the accurate self-estimate view (which is itself a version of the non-overestimation view). In addition, Tangney says humility is grounded in a willingness to acknowledge mistakes, intellectual openness, and a variety of other traits. She writes,

the key elements of humility seem to include: an accurate assessment of one's abilities and achievements (not low self-esteem, self-deprecation), an ability to acknowledge one's mistakes, imperfections, gaps in knowledge, and limitations (often vis-à-vis a higher power); openness to new ideas, contradictory information, and advice; keeping one's abilities and accomplishments-one's place in the world-in perspective; a relatively low self-focus, a -forgetting of the self... (2009)

The idea that humility requires us to have an accurate view of the self has been picked up by others..$^{15}$ This contrasts with the views of Lynch, Battaly, and Tanesini, who argue that intellectual humility does not require an accurate estimate of one's intellectual strengths and weaknesses.

The most plausible view, I think, is that one can neither overestimate one's intellectual strengths nor underestimate them too badly, although a fully accurate self-estimate isn't required. Following lan Church (2016), we may characterize intellectual humility as a virtuous mean between intellectual arrogance (too high a self-estimate) and intellectual servility (too low a selfestimate). But we need not take a firm stance on whether an accurate assessment of the self is necessary for humility. It is enough that humility is compatible with an accurate understanding of one's values, worth, and accomplishments. ${ }^{16}$

\footnotetext{
${ }^{15}$ For example, Gregg and Mahadevan (2014) say intellectual humility is "a realistic evaluation of one's epistemic capacities"; Church and Barrett (2016) say intellectual humility is "the virtue of accurately tracking what one could nonculpably take to be the positive epistemic status of one's own beliefs"; and Lavelock et al. (2014) say "humility involves having an accurate view of self, evidenced by honest selfevaluation and willingness to accept one's strengths and weaknesses." ${ }^{16}$ Whitcomb et al. (2017) have argued that a low concern for one's intellectual status is neither sufficient nor necessary for intellectual humility. For a reply, see Snow (2019) and Pritchard (2018).
} 
I'll wrap up this exploration of the literature on humility by drawing out some typical characteristics of the intellectually humble person. I do not pretend these are individually necessary or jointly sufficient, but I do claim that someone who exhibits a set of these qualities has something worth calling 'intellectual humility'.

The intellectual humble person will:

- not think too highly of themselves or be too impressed by their admired features ${ }^{17}$

- not think that one's beliefs or attitudes are better or more correct than other viewpoints $^{18}$

- not show conceit or be arrogant, which stems from a high opinion of oneself ${ }^{19}$

- not overestimate or exaggerate their good features or achievements ${ }^{20}$

- show low concern for how special their talents are ${ }^{21}$

- show low concern for how their intellect is perceived; i.e. will lack intellectual vanity 22

- not boast or brag about their intellectual accomplishments ${ }^{23}$

- not demand (and often refuse to accept) special treatment or honors, even when deserving ${ }^{24}$

- not be defensive when challenged or try to explain away their intellectual shortcomings ${ }^{25}$

\footnotetext{
${ }^{17}$ Roberts and Wood (2003); Garcia (2006); Kellenberger (2010); Hill and Laney (2017: 243); Pritchard (2018).

18 Tangney (2009); Toner et al. (2013); Krumrei-Mancuso and Rouse (2016).

${ }^{19}$ Roberts and Wood (2007); Kellenberger (2010); Church and Samuelson (2017); Lynch (2018).

${ }^{20}$ Flanagan (1996); Tangney (2000, 2009); Roberts and Wood (2003); Kellenberger (2010); Church and Samuelson (2017); Pritchard (2018); Tanesini (2018).

${ }^{21}$ Roberts and Wood (2003); Tangney (2009); Kellenberger (2010); Pritchard (2018).

22 Roberts and Wood (2003); Tangney (2009); Kellenberger (2010); Alfano et al. (2017).

${ }^{23}$ Samuelson et al (2015); Tanesini (2018).

${ }^{24}$ Kellenberger (2010); Wright et al. (2017), Priest (2017: 470); Whitcomb et al. (2017: 17); Tanesini (2018).

${ }^{25}$ Van Tongernan et al. (2014); Samuelson et al. (2015); Krumrei-Mancuso and Rouse (2016); Whitcomb et al. 2017; Tanesini (2018).
} 
- take complaints and criticism seriously, even when the criticizers are not authority figures ${ }^{26}$

- $\quad$ acknowledge their mistakes and shortcomings ${ }^{27}$

- have a propensity to defer to others ${ }^{28}$

- generously acknowledge the contributions of others ${ }^{29}$

- show open-mindedness to new ideas ${ }^{30}$

- show concern for (or 'own') their intellectual limitations ${ }^{31}$

This highlights the heterogeneity of behaviors and characteristics that philosophers and psychologists have taken to characterize intellectual humility. Given this heterogeneity, it is not surprising that several very different accounts of this virtue have been developed. I propose we take this heterogeneity at face value without succumbing to the philosophical urge-perhaps an imprint of Socrates's legacy - to find some deeper underlying unity to them all. ${ }^{32}$ As far as I'm concerned, all these traits gesture at something that arguably deserves the label 'intellectual humility'. We should therefore regard intellectual humility as a multifaceted and multilayered virtue. $^{33}$

\footnotetext{
${ }^{26}$ Roberts and Wood (2007); Hoyle et al. (2016); Priest (2017: 470); Whitcomb et al. (2017).

${ }^{27}$ Roberts and Wood (2007); Tangney (2009); Kellenberger (2010); Church and Samuelson (2017); Whitcomb et al. (2017); Tanesini (2018).

${ }^{28}$ Whitcomb et al. (2017).

${ }^{29}$ Tangney (2000); Kellenberger (2010); Tanesini (2018).

${ }^{30}$ Samuelson et al. (2015); Krumrei-Mancuso and Rouse (2016); Church and Samuelson (2017); Priest (2017: 470); Tanesini (2018).

${ }^{31}$ Tangney (2009); Whitcomb et al. (2017), Priest (2017: 470); Tanesini (2018).

${ }^{32}$ As Hill and Laney (2017: 245) say, "a complex combination of characteristics comprise the construct of humility". Tangney $(2000,2009)$ also seems happy to accept the heterogeneity of intellectual humility. Tanesini (2018) acknowledges that intellectual humility is "a complex virtue" and its characteristics are therefore "a heterogeneous bunch". But she still seeks an underlying unity.

${ }^{33}$ Following Kellenberger (2010), we might say humility is a "polythethic concept". A polythetic concept applies to a class that is not defined by necessary and sufficient properties, but instead its members are marked by characteristics shared by many but not all instances (i.e. family resemblances). This does not prevent us from saying anything useful about intellectual humility.
} 


\section{Are the Epistemically Egocentric More Likely to Be Intellectually Humble?}

Now let's return to the alleged connection between epistemic egocentrism and intellectual humility. My hypothesis is that epistemically egocentric individuals are more likely to possess a variety of traits that are characteristic of intellectual humility. Below I will explain why.

At least one important dimension of intellectual humility is that one seems insensitive to, or unconcerned with, how truly special one's aptitudes are. In addition, the intellectually humble person will not think too highly of herself or be too impressed by the features for which they she is admired. Imagine a brilliant philosopher who, when praised for her intellect by others, says (and genuinely believes): “I’m really not all that special. My colleagues are just as talented as I am, and any one of them might have solved the mind-body problem instead of me. It was just luck that the solution occurred to me. Also, my colleagues deserve just as much credit because they have been discussing this problem with me for years and they've steered my thinking in the right direction." Such a person seems genuinely intellectually humble in spite of her brilliance. What might explain why she is relatively insensitive to the specialness of her aptitudes?

One way in which a person can achieve this hallmark of humility is by implicitly imbuing others with the sorts of aptitudes they do not really have, or by overrating the ease with which they could acquire such aptitudes. ${ }^{34}$ This is illustrated by the example of the brilliant professor, who seems to genuinely think that her colleagues are just as intelligent (they're not) and could just as easily have achieved the same remarkable accomplishments (they couldn't have). Notice, however, that by implicitly imbuing others with intellectual aptitudes they do not really have, our brilliant professor is being epistemically egocentric. ${ }^{35}$ She seems to automatically and implicitly

\footnotetext{
${ }^{34}$ Royzman (2003) makes this point, but he doesn't develop the idea.

${ }^{35}$ The literature on epistemic egocentrism often slides between talk of attributing one's knowledge to others, one's mental states to others, and one's aptitudes to others. I interpret 'epistemic egocentrism' broadly to include any of these overattributions.
} 
elevate her colleagues to her own rank of intelligence. This egocentric explanation seems especially plausible when we remember that humility requires us to not provide too low an assessment of our own intellectual strengths. After all, self-disparagement would explain why one does not think too highly of oneself or is not too impressed by one's admirable features; but self-disparagement is (at least on many accounts) incompatible with humility. One cannot be intellectually servile and remain humble. Thus, we cannot appeal to self-disparagement to explain why the brilliant philosopher in our example is humble. To truly think she is "not so special", she may therefore be overestimating the epistemic standing of others (rather than underestimating her own).

This is just the stance of the more knowledgeable individual in the epistemic egocentrism paradigm. A participant is endowed with privileged information and asked to consider a situation from the perspective of someone who lacks that information. When we are being epistemically egocentric, we will find it difficult to imagine the world from the perspective of someone who lacks the information or intellectual aptitudes that we possess. ${ }^{36}$ As a result, we become overly confident in other people's epistemic standing; viz., we mistakenly assume they are in a stronger epistemic position than is truly the case. And from the perspective of the less knowledgeable individual, it may seem like the gifted person is denying herself some well-deserved credit for her intellectual accomplishments. Thus, intellectual humility may just be epistemic egocentrism viewed from the perspective of another individual.

\footnotetext{
${ }^{36}$ There is some work suggesting that humility is other-focused in a sense that requires taking other people's point of view into account (Nadelhoffer and Wright 2017). This seems to contrast with my own view, which treats epistemic egocentrism as a form of perspective-taking failure. However, these views do have something in common: they both require a subject to consider the world from the perspective of another person. The crucial difference is that, on my account, the epistemically egocentric person mistakenly imputes others with her own mental states (e.g., knowledge) and then views herself from what she mistakenly assumes to be the perspective of another individual. Another important difference is that Nadelhoffer and Wright are providing an account of humility in general, not intellectual humility, so their focus is on "promoting and protecting others' wellbeing and seek[ing] to make a difference when/where [one] reasonably can". Finally, they characterize a high other-focus in part as "recognition of the value of others" and "openness to new ideas", and my account does explain why the epistemically egocentric person would exhibit this behavior.
} 
This hypothesis has a lot of explanatory power, for it can explain a variety of qualities that are characteristic of intellectual humility. As noted earlier, an intellectually humble person will tend not to think her beliefs or attitudes are better than the views of others. We might explain this by appealing to the fact that an epistemically egocentric outlook will lead one to view other perspectives as similar to one's own, and therefore on an epistemic par. It is the nature of belief that we cannot regard our own beliefs as false, so an epistemically egocentric individual will tend to think others' views are accurate too. This would lead one to think their own beliefs are not better or more correct than those of others.

This attitude will also operate as a natural check on conceit or arrogance, which stems from having a high opinion of oneself. If an intelligent person is epistemically egocentric, she may not think too highly of herself or be too impressed by her admired features; thus, she will have no grounding for conceit or arrogance. As a result, she will also be less likely to boast or brag about her intellectual accomplishments. Further, implicitly attributing impressive intellectual aptitudes to others (or overrating the ease with which they could acquire these aptitudes) would explain why the intellectually humble person would not demand-and often refuse to accept-special treatment or honors, even when deserving. It is because she genuinely does not believe that she merits such treatment or honors in comparison with others.

It is useful, at this point, to distinguish egocentrism from egoism and egotism. Egoism is the tendency to be motivated by self-interest, while egotism is the tendency to perceive oneself in excessively favourable ways. In the epistemic case, the egotistic person will tend to regard their own beliefs as better and more likely to be true than those of others. This can lead to arrogance. Intellectually humility, however, involves a lack of egotism and a low degree of self-centeredness in the domain of intellectual life (Leary and Terry 2012). Thus, if my hypothesis about the connection between egocentrism and humility is right, we can expect epistemically egocentric people to be less epistemically egotistic because intelligent people who are epistemic egocentric 
will not think too highly of themselves or be too impressed by their achievements. In short, the epistemically egocentric may be less likely to be epistemically egotistic. ${ }^{37}$

According to some scholars, intellectually humble people are also less likely to talk about what they know, are more likely to show curiosity and open-mindedness, are willing to take complaints and criticism seriously (even when the criticizers are not authority figures), and have an increased propensity to defer to others. These characteristics may also be explained, at least partially, by an epistemically egocentric stance. For example, we may be less motivated to talk about our knowledge if we assume that others already know what we do. After all, I needn't tell you that the U.S. House of Representatives just passed a spending bill with $\$ 5$ billion for Trump's border wall if I think you already know this. ${ }^{38}$ Further, epistemically egocentric people may remain curious and open-minded because one who thinks their knowledge is not so special is less likely to be complacent with what they know. In contrast, someone who thinks they are smarter than everyone else may be less driven to seek new knowledge. In addition, one who is overly confident in other people's epistemic standing may be more willing to accept feedback from others, including critical feedback from people who are not actually experts or authority figures in the relevant domain. Presumably, one who thinks their interlocutor is far less intelligent or knowledgeable about some issue will have less of an (epistemic) reason to heed their advice, and thus be less willing to defer to their judgment. By assuming that others have more epistemic authority than they do, the epistemically egocentric individual may be more willing to take their advice and defer to the judgment of others. This would also explain why the intellectually humble do not have a propensity to treat their intellectual inferiors relatively poorly on the basis of their

\footnotetext{
${ }^{37}$ This fits nicely with Roberts and Wood's $(2003,2007)$ claim that humility is opposite of egotism.

${ }^{38}$ I do not mean to imply that people only tell others things they presume are unknown to the listener. Various motivations may promote the discussion of information that is presumed to be common ground. However, I am following Grice's (1975) maxim of quantity, which states that cooperative conversational partners will not provide redundant information or more information than is necessary.
} 
intellectual inferiority (Whitcomb et al. 2017: 17). Indeed, it may explain why the intellectually humble agent has a deep respect for her intellectual community (Priest 2017: 470).

According to Priest (2017: 427), the intellectually humble person "sees himself in the same light as he sees all others." This comes very close to describing what happens when one exhibits the bias of epistemic egocentrism. But rather than seeming himself in the same light as he sees all others, the epistemically egocentric individual will see others as he sees himself. In other words, "intellectual humility is exemplified in treating the intellect of others like the intellect of one's own" (ibid). Although there may be occasions when he mentions his own intellectual aptitudes or achievements, he is just as likely to mention the aptitudes or achievements of others. Further, it is not incompatible with humility to have an accurate view of the strength of one's own epistemic position (as discussed in the previous section). But the humble person may have an inaccurate view of the epistemic standing of others. Again, this would explain why humble people do not consider their own accomplishments very special, even though they do not have too low an opinion of their own intellectual aptitudes or achievements.

Thus, while there is a sense in which it is right to say the intellectual humble "recognize the limits of their own knowledge" (i.e. they do not exaggerate their own epistemic standing), there is also a sense in which the intellectually humble might fail to appreciate the limits of their knowledge (i.e. they may attribute too much epistemic authority to others). By extending our knowledge or intellectual aptitudes too far, we draw inaccurate boundaries between the contents and capacities of our own minds and those of others.

None of this is to say that epistemic egocentrism is necessary or sufficient for intellectual humility. We can easily imagine, for instance, an epistemically egocentric person who is quite arrogant. Consider my friend Byron, who loves to play charades and yet consistently overestimates how easy it will be for others to guess the answers to his wild gesticulations. Byron is being epistemically egocentric; but his egocentrism does not prevent him from also thinking 
he's far better at charades than everyone else, nor does it stop him from making others feel inadequate for being unable to guess the correct answer. He often says things like, "I'm the best at charades" and "I almost never lose at this game" despite the fact that both these claims are entirely false. Thus, I am neither claiming that intellectual humility requires epistemic egocentrism, nor am I claiming that epistemic egocentrism is sufficient for intellectually humility. Rather, I am claiming that we should expect epistemic egocentrism and intellectual humility to correlate: we have reason to think that epistemically egocentric individuals are more likely to possess a variety of traits that are characteristic of intellectual humility.

\section{Virtues and Biases}

A virtue is an excellent trait of character. We value the virtues because they tend to make people better or bring about valuable states of affairs. A moral virtue, for instance, normally helps make people, either constitutively or causally, good morally. Presumably, then, an intellectual virtue is a trait that normally helps to make people good epistemically. And yet cognitive biases, such as epistemic egocentrism, are often regarded as epistemic shortcomings. Is this a problem for my view? Can a cognitive bias give rise to an intellectual virtue?

I see no reason to think not. It might be dubious to claim that a cognitive bias is itself an intellectual virtue. This would require us to regard a bias, such as epistemic egocentrism, as an excellent character trait. But I am not claiming that epistemic egocentrism is a virtue. Rather, my claim is that epistemic egocentrism may explain the presence of certain traits that are characteristic of intellectual humility. Consider an analogy. According to some recent neuroscience, forgetfulness is a sign of greater intelligence (Richards and Frankland 2017). The explanation, roughly, is that smarter people will tend to forget irrelevant details and instead focus on things that will help them make decisions in the real world. Let's suppose this is correct. In this case, we may regard intelligence as a virtue without thereby admitting that forgetfulness is 
a virtue. The point is that forgetfulness (something we generally regard as an epistemic shortcoming) is correlated with higher intelligence (something we regard as a virtue). We may still value intelligence without valuing forgetfulness; likewise, we may value intellectual humility without thereby valuing epistemic egocentrism. ${ }^{39}$

An interesting project would be to explore how intellectual humility correlates with other cognitive biases. Many authors have assumed that intellectual humility will diminish certain biases (e.g., Whitcomb et al. 2017; Samuelson and Church 2015; Ballantyne MS), but it is worth asking precisely how it would function as a corrective to flawed cognitive processing. I will not pursue this question here. ${ }^{40}$

\section{Limitations of My Account}

I have argued that epistemic egocentrism can explain why an individual would possess a variety of traits that are characteristic of intellectual humility. In a chapter on humility, however, it is only fitting to discuss some limitations of my account. For example, epistemic egocentrism will not explain the motivational component of intellectual humility whereby an individual pursues knowledge more for the sake of knowledge than for the sake of social esteem, prestige, admiration from others, or general self-enhancement. If one thinks that intellectual humility requires one to "love truth for its own sake", then epistemic egocentrism seems poorly equipped to explain this component of humility. Further, epistemic egocentrism doesn't seem to sufficiently capture other qualities that are sometimes associated with intellectual humility, such as a stable sense of self-worth, being aware and forgiving of human intellectual shortcomings, and not being envious of others' successes (Tanesini 2018).

\footnotetext{
${ }^{39}$ The analogy holds up in another way: it would be mistaken to claim that forgetfulness is either necessary or sufficient for high intelligence, just as it would be mistaken to claim that epistemic egocentrism is either necessary or sufficient for intellectual humility.

${ }^{40}$ See Samuelson and Church (2015: 1101-2, 1106-7) for more discussion.
} 
Epistemic egocentrism may also lead one to seem less intellectually humble in certain circumstances. For example, a speaker who overestimates what his listeners know may talk over their heads, which might seem in tension with being humble. Consider the scholar who uses academic jargon, or makes reference to obscure historical figures, in conversation with people who have no expertise in the relevant area ${ }^{41}$ Such a person may seem pretentious or intellectually snobbish. Further, it is often said that open-mindedness is a central trait of intellectual humility, but epistemic egocentrism may sometimes lead one to be less open to the opinions of others; for instance, one might be less willing to consider the opinions of others if one thinks other people already know what she knows. Finally, it may be true that some people are better at inhibiting epistemic egocentrism than others, and perhaps humility is something that could facilitate this. Thus, the relationship between intellectual humility and epistemic egocentrism may be more complicated than I have explored here.

An area for future study is intellectual humility in young children. The developmental literature is replete with studies that document epistemic egocentrism in young children, so my view should predict that children would likely exhibit the same characteristics of intellectual humility. I do not have space to explore this topic here, but it is worth pointing out that young children do seem incredibly open-minded, willing to defer to others, unconcerned with how special their talents are, and tend to lack intellectual vanity. We are also told that Jesus Christ made the following remark: "Truly, as I say to you, unless you turn and become as children, you will never enter the kingdom of Heaven. Whoever humbles himself like a child, he is the greatest in the kingdom of Heaven" (Matthew 18:3-4, emphasis mine). So at least some people seem to think children exemplify humility.

\footnotetext{
${ }^{41}$ As we all know, in 1642 Ambrose Gascoigne observed this phenomenon, but he called it 'proiectura mentis'.
} 


\section{Conclusion}

I have argued that an epistemically egocentric individual is perhaps more likely to possess a variety of traits that are characteristic of intellectual humility. This is noteworthy because intellectual humility is often regarded as an antidote to cognitive biases, whereas I claim that an epistemically egocentric bias may help foster an intellectual virtue. I do not claim to have substantiated this conjecture in a conclusive way, but I hope to have lent some credence to it. The philosophical and psychological work on intellectual humility is vigorous and ongoing, but still in its infancy. I hope the work reviewed here suggests a promising avenue for further exploration. 


\section{Works Cited}

Alfano, M, lurino, K., Stey, P., Robinson, B., Christen, M., Yu, F. and \& Lapsley, D. (2017).

Development and validation of a multi-dimensional measure of intellectual humility. PLOS ONE 12 (8): e0182950.

Allhoff, F. (2009). What Is Modesty? International Journal of Applied Philosophy 23 (2): 165-187.

Anonymous. (1981). The Cloud of Unknowing, trans. James Walsh. Mahwah, N.J.: Paulist Press.

Aquinas, St. T. ([1485] 1972).Summa Theologiae, vol. 44, trans. Thomas Gilby. Cambridge, UK: Blackfriars.

Ballantyne, Nathan (MS). Intellectual Humility: A Brief Introduction.

Church, I. (2016). The Doxastic Account of Intellectual Humility. Logos and Episteme 7 (4): 413433.

Church, I. M. \& Barrett, J. (2016). Intellectual Humility. In E. L. Worthington Jr., D. E. Davis, \& J. N. Hook (Eds.), Handbook of Humility: Theory, Research, and Applications. Routledge.

Church, I. M. \& Samuelson, P. L. (2017). Intellectual Humility: An Introduction to the Philosophy and Science. Bloomsbury Academic.

Driver, J. (2001). Uneasy Virtue. Cambridge University Press.

Flanagan, O. (1996). Self-expression. Oxford University Press.

Garcia, J. L. A. (2006). Being unimpressed with ourselves: Reconceiving humility. Philosophia 34 (4): 417-435.

Gregg, A. P. and Mahadevan, N. (2014). Intellectual Arrogance and Intellectual Humility: An Evolutionary-Epistemological Account. Journal of Psychology and Theology 42: 7-18. 
Grice, H. P. (1975). Logic and Conversation. In P. Cole and J. Morgan (Eds.), Syntax and Semantics. Academic Press.

Hare, S. (1996) The Paradox of Moral Humility. American Philosophical Quarterly 33 (2): 235-241.

Hazlett, A. (2012). Higher-Order Epistemic Attitudes and Intellectual Humility. Episteme 9 (3):

205-223.

Heath, C. \& Heath, D. (2006). The Curse of Knowledge. Harvard Business Review.

Hill, P. C., \& Laney, E. K. (2017). Beyond self-interest: Humility and the quieted self. In K. W.

Brown \& M. R. Leary (Eds.), The Oxford handbook of hypo-egoic phenomena. Oxford University Press.

Hoyle, R., Davisson, E., Diebels, K. \& Leary, M. (2016). Holding specific views with humility: Conceptualization and measurement of specific intellectual humility. Personality and Individual Differences 97: 165-172.

Kellenberger, J. (2010). Humility. American Philosophical Quarterly 47 (4): 321-336.

Krumrei-Mancuso, E. \& Rouse, S. (2016). The Development and Validation of the Comprehensive Intellectual Humility Scale. Journal of Personality Assessment 98 (2): 209-221.

Lavelock, C. R., Worthington, Jr., E., Davis, D., Griffin, B., Reid, C., Hook, J., \& Daryl R. Van Tongeren. (2014). The Quiet Virtue Speaks: An Intervention to Promote Humility. Journal of Psychology and Theology 42: 99-110.

Leary, M. R., \& Terry, M. L. (2012). Hypo-egoic mindsets: Antecedents and implications of quieting the self. In M. R. Leary, M. R. Leary, J. P. Tangney (Eds.) Handbook of self and identity (2nd ed.). Guilford Press, pp. 268-288.

Lewis, C. S. (Source: thesecertainthings) September 2012 3:09 pm 20 notes http:// thesecertainthings.tumblr.com/post/31873965746/humility-is-not-thinking-less-of-yourself-but. 
Lynch, M. (2018). Arrogance, truth and public discourse. Episteme 15 (3): 283-296.

McArthur, T. (1998). Oxford English dictionary. Concise oxford companion to the English language. Retrieved January 09, 2015, from Encyclopedia.com. http://www.encyclopedia. com/doc/1029- oxfordenglishdictionary.html Nadelhoffer, T., Wright, J. C., Echols, T., and Venezia, K. (2017). Some Varieties of Humility Worth Wanting. Journal of Moral Philosophy 14 (1): 168-200.

Nadelhoffer, T., \& Wright, J. C. (2017). The Twin Dimensions of the Virtue of Humility: Low SelfFocus and High Other-Focus. In W. Sinnott-Armstrong and C. B. Miller (Eds.), Moral Psychology: Virtues and Vices. Cambridge: MIT Press.

Nickerson, R. S. (1999). How We Know -And Sometimes Misjudge-What Others Know: Imputing One's Own Knowledge to Others. Psychological Bulletin 125: 737-759.

Priest, M. (2017). Intellectual Humility: An Interpersonal Theory. Ergo: An Open Access Journal of Philosophy 4.

Pritchard, D. (2018). Intellectual humility and the epistemology of disagreement. Synthese. Online First: https://doi.org/10.1007/s11229-018-02024-5

Richards, B. and Frankland, P. (2017). The Persistence and Transience of Memory. Neuron 94 (6): 1071-1084.

Richards, N. (1992). Humility. Temple University Press.

Roberts, R. and Wood, J. (2007). Intellectual Virtues: An Essay in Regulative Epistemology. Oxford University Press.

Roberts, R. and Wood, J. (2003). Humility and epistemic goods. In L. Zagzebski \& M. DePaul (Eds.), Intellectual Virtue: Perspectives from Ethics and Epistemology. Oxford University Press. 
Royzman, E. B., Cassidy, K. W., \& Baron, J. (2003). "I know, you know": Epistemic egocentrism in children and adults. Review of General Psychology, 7(1): 38-65.

Samuelson, P. L., \& Church, I. M. (2015). When cognition turns vicious: Heuristics and biases in light of virtue epistemology. Philosophical Psychology 28 (8): 1095-1113.

Samuelson P. L., Jarvinen, M., Paulus, T., Church, I. M., Hardy, S., \& Barrett, J. (2015). Implicit theories of intellectual virtues and vices: A focus on intellectual humility. Journal of Positive Psychology 10 (5): 389-406.

Schueler, G. F. (1997). Why Modesty Is a Virtue. Ethics 107: 467-85.

Sidgwick, H. 1907/1962. The Methods of Ethics, 7th ed. University of Chicago Press.

Sinha, G.A. (2011). Modernizing the Virtue of Humility. Australasian Journal of Philosophy 90 (2): $259-274$.

Snow, N. (2019). Intellectual Humility. In H. Battaly (Ed.), The Routledge Handbook of Virtue Epistemology. Routledge.

Tanesini, A. (2018), Intellectual Humility as Attitude. Philosophy and Phenomenological Research 96: 399-420.

Tangney, J. (2000). Humility: Theoretical Perspectives, Empirical Findings, and Directions for Future Research. Journal of Social and Clinical Psychology 19: 70-82.

Tangney, J. (2009). Humility. In S. J. Lopez and C. R. Snyder (Eds.), Oxford handbook of positive psychology. Oxford University Press.

Taylor, G. (1985). Pride, Shame and Guilt. Clarendon Press.

Toner, K., Leary, M. R., Asher, M. W., \& Jongman-Sereno, K. P. (2013). Feeling Superior Is a Bipartisan Issue: Extremity (Not Direction) of Political Views Predicts Perceived Belief Superiority. Psychological Science 24 (12): 2454-2462. 
Van Tongeren, D., Davis, D., \& Hook, J. (2014). Social benefits of humility: Initiating and maintaining romantic relationships. The Journal of Positive Psychology 9 (4): 313-321.

Whitcomb, D., Battaly, H., Baehr, J., \& Howard-Snyder, D. (2017). Intellectual Humility: Owning Our Limitations. Philosophy and Phenomenological Research 94 (3): 509-539.

Wittgenstein, L. (1964). Blue and Brown Books. Blackwell.

Wright, J.C., Nadelhoffer, T., Ross, I. T., \& Sinnott-Armstrong, W. (2018.) Be it ever so humble: Proposing a dual-dimension account and measurement of humility. Self and Identity 17 (1): 92125. 